\title{
Penerapan Turbin AWI-E1000T untuk Pembangkit Listrik Tenaga Angin di Desa Temajuk
}

\author{
Ayong Hiendro ${ }^{1)}$, Ismail Yusuf ${ }^{2}$ \\ 1)2) Universitas Tanjungpura, Pontianak, Indonesia
}

Corresponding Author: Ayong Hiendro, ayong.hiendro@ee.untan.ac.id

\begin{abstract}
Abstrak: Daerah-daerah dengan kondisi geografis tertentu, seperti daerah pesisir pantai dan pegunungan, umumnya memiliki potensi angin yang sangat baik. Desa Temajuk merupakan daerah pesisir pantai yang memiliki potensi energi angin untuk dapat dimanfaatkan sebagai alternatif sumber listrik bagi masyarakatnya yang masih belum terlayani oleh jaringan listrik PLN. Kegiatan pengabdian kepada masyarakat ini bertujuan untuk memasang turbin angin sebagai pembangkit listrik tenaga angin (PLTA) di Desa Temajuk. Survei lokasi, pengukuran kecepatan angin dan pemasangan turbin angin dilakukan di Desa Temajuk yang berbatasan langsung dengan Malaysia. Hasil pengukuran pada ketinggian $20 \mathrm{~m}$ di lokasi didapatkan kecepatan angin rata-rata sebesar 1,6 m/s. Nilai kecepatan ini cukup memadai untuk aplikasi pembangkit listrik tenaga angin di daerah tersebut. Penerapan turbin angin AWI-E1000T dengan spesifikasi kecepatan cut-in 1,5 m/s menghasilkan energi listrik sebesar $1861 \mathrm{kWh}$ per tahun. Dengan tersedianya infrastruktur listrik dapat meningkatkan produktivitas masyarakat Desa Temajuk.
\end{abstract}

Kata Kunci: daerah perbatasan, energi terbarukan, kecepatan angin, turbin angin, pembangkit listrik

Abstract: Areas with certain geographical conditions, such as coastal areas and mountains, generally have very good wind potential. Temajuk Village is a coastal area that has the potential for wind energy to be used as an alternative source of electricity for the community, which is still not served by the PLN electricity network. This community engagement activity aims to install a wind turbine as a wind power generator in Temajuk Village. The location survey, wind speed measurement and the installation of a wind turbine were carried out in Temajuk Village which is directly adjacent to Malaysia. The measurement results at the location obtained an average wind speed of $1.6 \mathrm{~m} / \mathrm{s}$ at an altitude of $20 \mathrm{~m}$. This speed value is quite adequate for wind power applications in the area. The application of the AWI-E1000T wind turbine with a cut-in speed specification of $1.5 \mathrm{~m} / \mathrm{s}$ is capable of producing electrical energy of $1861 \mathrm{kWh}$ per year. With the availability of electricity infrastructure, it can increase the productivity of the people of Temajuk Village.

Keywords: border area, electricity generation, renewable energy, wind speed, wind turbine

\section{Pendahuluan}

Kondisi geografis wilayah Indonesia sangat luas dan memiliki ribuan pulau dengan penyebaran penduduk yang belum merata. Hal demikian menyebabkan masyarakat Indonesia belum seluruhnya dapat menikmati layanan energi listrik (Adam, 2016; Aminudin, 2020).

Selain itu, kondisi energi dan tantangan energi saat ini menunjukkan pemanfaatan energi terbarukan di Indonesia masih sangat kecil serta keterbatasan infrastruktur menyebabkan rendahnya akses masyarakat terhadap energi listrik (Hiendro et al., 2013). Pemanfaatan sumber energi terbarukan yang masih rendah ini dipengaruhi oleh biaya investasi yang tinggi dan 
harganya belum dapat menyaingi pembangkit listrik dengan bahan bakar fosil (Yunita $d k k$., 2019).

Bagi masyarakat perbatasan di Kalimantan Barat, sebagian besar belum menikmati layanan energi listrik, karena : a) mahalnya jaringan transmisi untuk menjangkau daerah-daerah tersebut, b) sebaran penduduk yang berjauhan terhadap masing-masing permukiman dan jumlah penduduk yang sangat sedikit menyebabkan biaya investasi menjadi sangat mahal dan tidak menguntungkan, c) daya listrik yang tersedia saat ini jauh lebih rendah dari kebutuhan listrik masyarakat, d) pemerintah hanya mengandalkan PLN untuk menyediakan energi listrik, sehingga beban PLN semakin berat apalagi dana yang tersedia sangat terbatas, e) potensi sumber energi terbarukan pada umumnya belum dimanfaatkan dengan optimal, dimana PLN masih mengandalkan pembangkit berbahan bakar solar (PLTD) yang tidak ekonomis karena biaya bahan bakarnya cukup mahal. Padahal berdasarkan RUPTL PT PLN 2018-2027 (Menteri ESDM RI, 2018), target bauran energi untuk pembangkit tenaga listrik yang bersumber dari energi terbarukan di Indonesia pada akhir tahun 2025 harus sudah mencapai $23 \%$.

Energi angin merupakan salah satu bentuk energi terbarukan yang memiliki potensi yang sangat signifikan dan menjadi perhatian yang cukup besar pada saat ini (Rehman et al., 2018). Akan tetapi pemanfaatan energi angin sebagai sumber pembangkit tenaga listrik di Indonesia pada tahun 2019 baru mencapai kapasitas 76 MW. Padahal di wilayah Asia, pencapaian pembangunan pembangkit listrik tenaga angin (PLTA) sudah sebesar 249,08 GW (Bahrami et al., 2019).

Daerah perbatasan di Kabupaten Sambas, secara geografis memiliki potensi energi angin yang cukup tinggi karena berada di pesisir pantai. Wilayah ini umumnya masih kurang tersentuh oleh program-program pembangunan dari pemerintah, terutama layanan kebutuhan energi listrik (Bupati Sambas, 2019). sehingga masyarakatnya menjadi relatif tertinggal apabila dibandingkan dengan masyarakat negara Malaysia yang bermukim berbatasan langsung di dekatnya. Gambar 1 menunjukkan lokasi Desa Temajuk yang terletak di posisi lintang dan bujur: $2^{\circ} 01^{\prime} 22,6^{\prime \prime} \mathrm{LU}$ dan $109^{\circ} 37^{\prime} 00,5^{\prime \prime} \mathrm{BT}$.

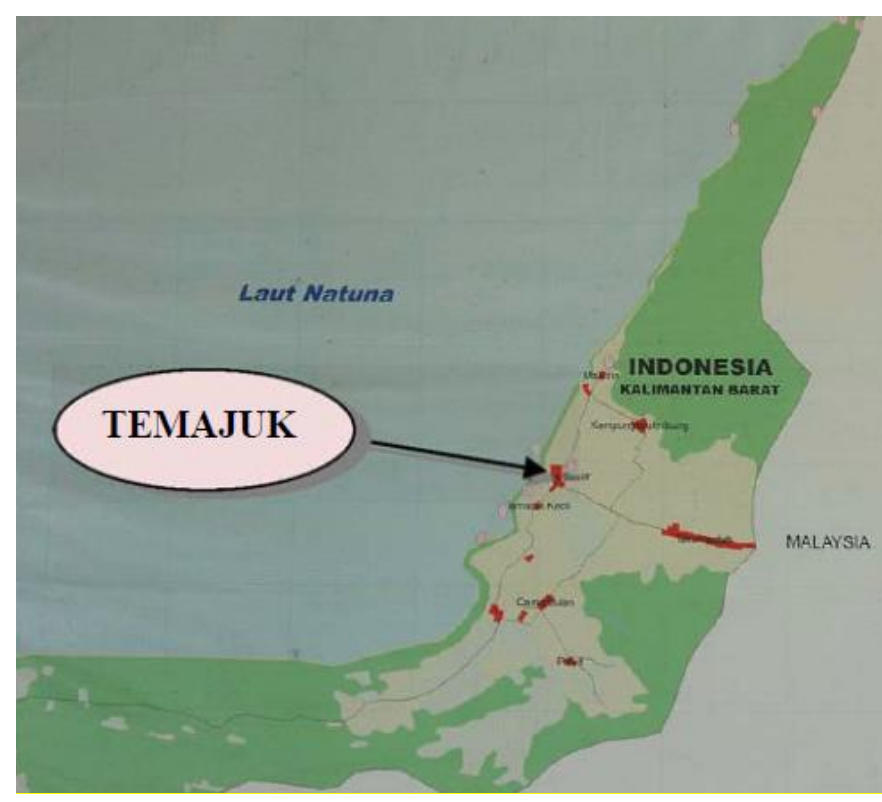

Gambar 1. Peta Desa Temajuk 
Mengacu kepada prioritas nasional pembangunan (Presiden RI, 2018; Mendes PDTT, 2019), perlu mengupayakan pengoptimalan pengelolaan potensi sumber energi lokal untuk memberikan energi listrik yang mencukupi bagi masyarakat yang bermukim di wilayah perbatasan. Oleh karena itu kegiatan pengabdian kepada masyarakat ini bertujuan memanfaatkan potensi energi angin lokal dengan memasang PLTA sebesar $1 \mathrm{~kW}$ dengan menggunakan turbin angin AWI-E1000T untuk kebutuhan energi listrik bagi masyarakat di Desa Temajuk.

\section{Metodologi}

Mitra pengabdian kepada masyarakat adalah masyarakat di Desa Temajuk. Desa Temajuk adalah desa yang berada di wilayah administratif Kecamatan Paloh (Kabupaten Sambas, Kalimantan Barat).

Terdapat tiga tahapan yang dilakukan dalam proses pengabdian kepada masyarakat, yang terdiri dari: a) proses persiapan, b) proses pelaksanaan, dan c) proses evaluasi hasil. Pada proses persiapan, dilakukan survei untuk mengetahui gambaran dan topografi lokasi kegiatan serta pengukuran kecepatan angin di lokasi selama tujuh hari dan setiap hari selama 24 jam. Pengukuran kecepatan angin menggunakan perangkat anemometer PCE-FWS20 pada ketinggian 20 meter. Selanjutnya proses pelaksanaan dilakukan untuk pemasangan dan instalasi pembangkit listrik tenaga angin. Perlengkapan PLTA yang dipasang dan diinstalasi terdiri turbin angin tipe AWI-E1000T, menara besi setinggi 20 meter, inverter dan perangkat baterai untuk penyimpanan energi listrik seperti ditumjukkan pada diagram blok Gambar 2.

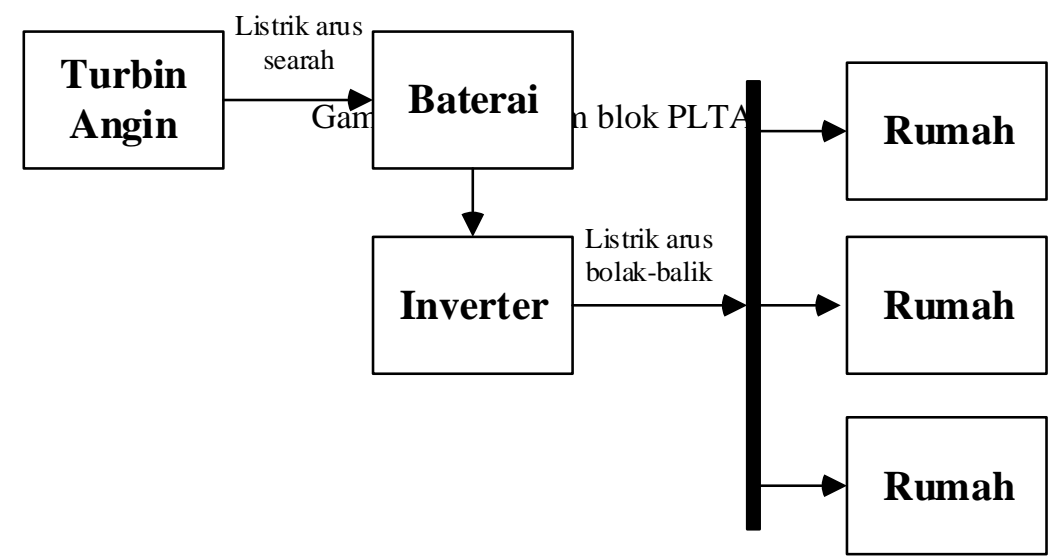

Pada tahap akhir, proses evaluasi dilakukan untuk mengetahui kinerja turbin angin dalam membangkitkan energi listrik ketika melayani kebutuhan beban listrik masyarakat. Selain itu untuk memprediksi energi listrik yang akan dibangkitkan oleh PLTA selama kurun waktu satu tahun, digunakan data sekunder dan karakteristik daya turbin angin. Analisis biaya investasi dengan nilai internal rate of return, IRR $=5 \%$ juga dilakukan untuk mendapatkan nilai biaya PLTA dengan satu turbin angin $1 \mathrm{~kW}$. 


\section{Hasil dan Pembahasan}

\section{A. Hasil}

Lokasi yang dipilih menjadi tempat pemasangan PLTA terletak di dataran tinggi dengan elevasi $8 \mathrm{~m}$ dari atas permukaan laut pada posisi titik koordinat: $02^{\circ} 00^{\prime} 20,2^{\prime \prime} \mathrm{LU}, 109^{\circ} 36^{\prime} 01,3$ " BT yang berhadapan langsung dengan Laut Natuna.

Pengukuran kecepatan angin dilakukan menggunakan perangkat anemometer PCEFWS20. Durasi pengukuran dan pengambilan data pada umumnya disesuaikan dengan kebutuhan. Agroklimatologi mempersyaratkan pengukuran kecepatan angin selama 24 jam. Dari data-data hasil pengukuran tersebut selanjutnya dapat diprediksi kecepatan angin mingguan, bulanan dan tahunan. Selain itu untuk pengukuran kecepatan angin dalam periode interval yang lebih singkat dapat dilakukan pada periode waktu pagi, siang, dan malam. Di dalam kegiatan ini, pemasangan anemometer dilakukan pada ketinggian 20 meter dari atas permukaan tanah seperti tampak pada Gambar 3.

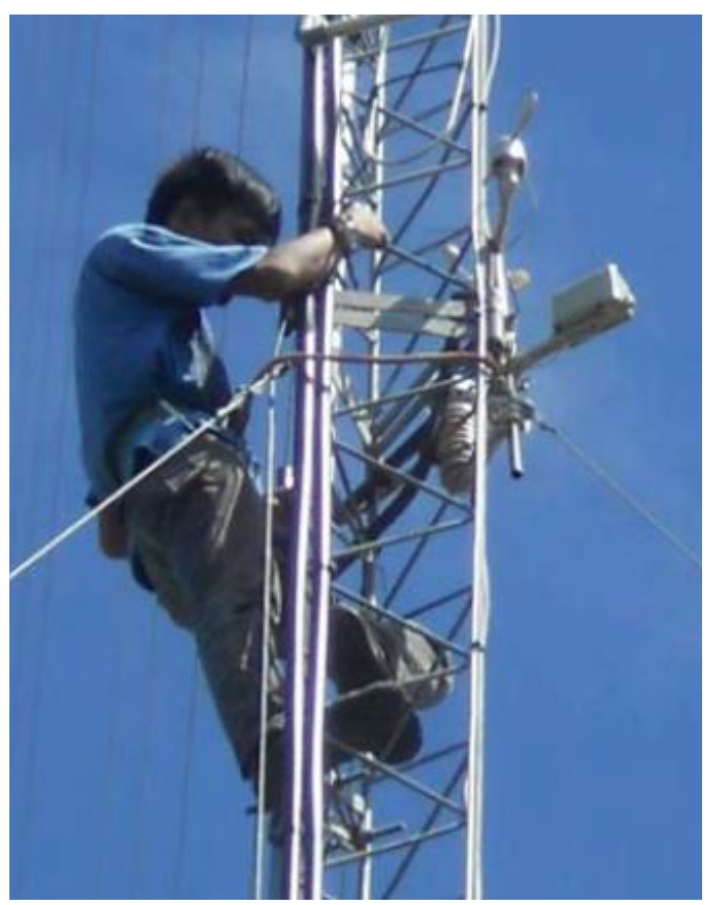

Gambar 3. Pemasangan anemometer PCE-FWS20

Hasil pengukuran kecepatan angin di lokasi ditunjukkan pada Gambar 4. Dari data tersebut diketahui kecepatan angin rata-rata adalah sebesar $1,6 \mathrm{~m} / \mathrm{s}$ dan kecepatan tertinggi adalah 7,5 m/s. Berdasarkan data hasil pengukuran tersebut maka pilihan turbin angin yang cocok untuk dipasang di Desa Temajuk adalah AWI-E1000T yang memiliki spesifikasi kecepatan cut-in sebesar 1,5 m/s. Selanjutnya gambar 5 menunjukkan hasil pemasangan PLTA dengan satu turbin angin AWI-E1000T. 


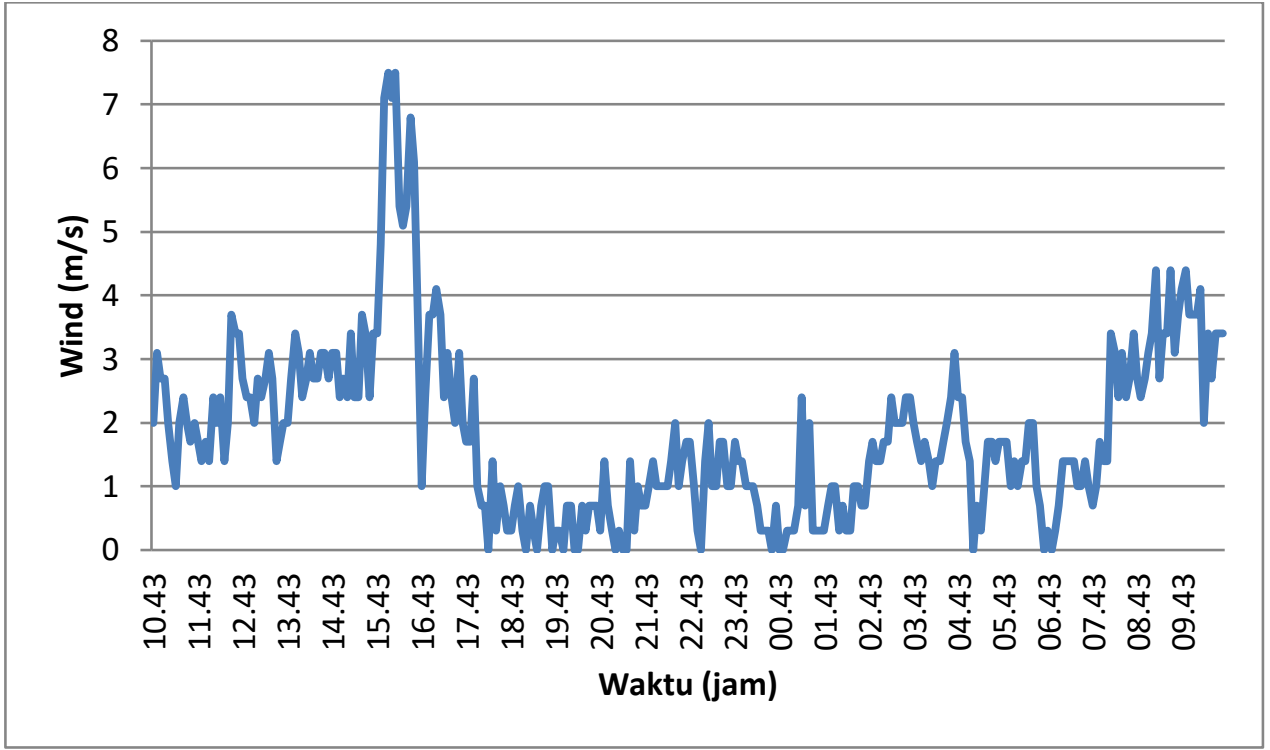

Gambar 4. Data kecepatan angin di lokasi Desa Temajuk

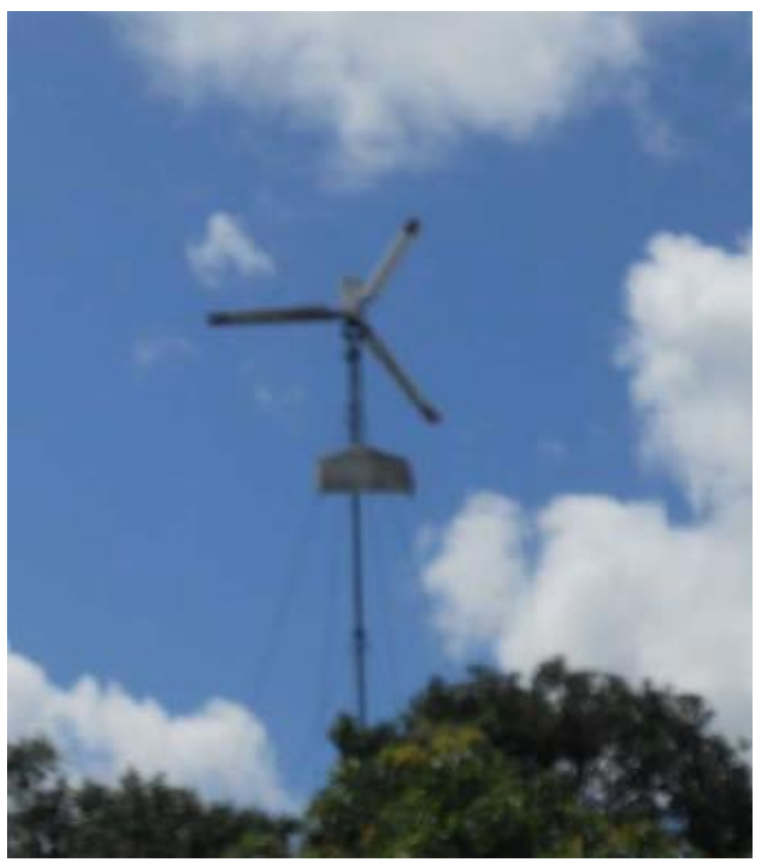

Gambar 5. Pembangkit listrik tenaga angin (PLTA)

\section{B. Pembahasan}

Sistem PLTA memiliki komponen-komponen utama antara lain: turbin angin, baterai dan inverter. Turbin angin yang digunakan adalah jenis turbin angin AWI-E1000T dengan spesifikasi sebagai berikut:

a) Rating: $1 \mathrm{~kW}$ (pada kecepatan angin $=14 \mathrm{~m} / \mathrm{s}$ )

b) Kecepatan cut-in : 1,0 - 1,5 m/s 
Karakteristik kurva daya turbin angin berdasarkan data-sheet AWI-E1000T (Wind Turbine 1KW Catalogue) ditunjukkan pada Gambar 6.

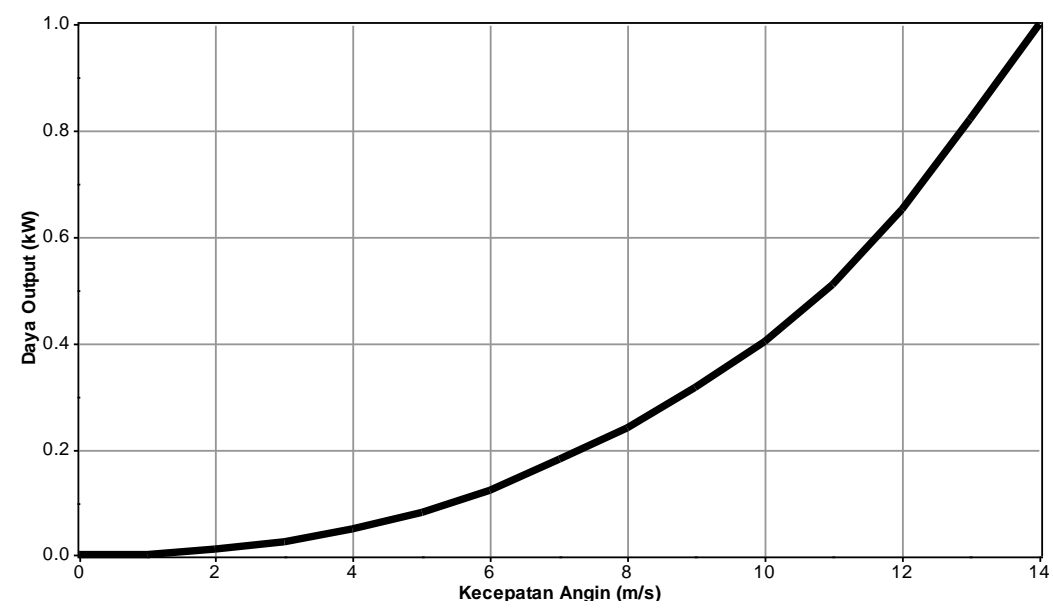

Gambar 6. Kurva daya AWI-E1000T

Dengan menggunakan turbin angin AWI-E1000T, energi listrik yang dihasilkan adalah listrik arus searah. Sebagian dari energi listrik arus searah tersebut dimanfaatkan untuk mengisi baterai. Fungsi baterai adalah untuk mengatasi fluktuasi energi listrik yang dibangkitkan oleh PLTA, karena kecepatan angin memiliki karakteristik yang berubah-ubah sepanjang waktu tergantung kepada kondisi cuaca. Untuk melayani beban listrik arus bolak-balik, maka diperlukan perangkat inverter sebagai alat konversi listrik arus searah ke listrik arus bolak-balik.

Daya listrik rata-rata per bulan yang dapat diproduksi oleh turbin angin dengan kondisi kecepatan angin yang ada di Desa Temajuk ditunjukkan pada gambar 7. Dari hasil analisis listrik keluaran yang mampu dibangkitkan, diperoleh produksi energi listrik rata-rata adalah sebesar 0,21 W dan energi listrik total sebesar $1861 \mathrm{kWh}$ per tahun.

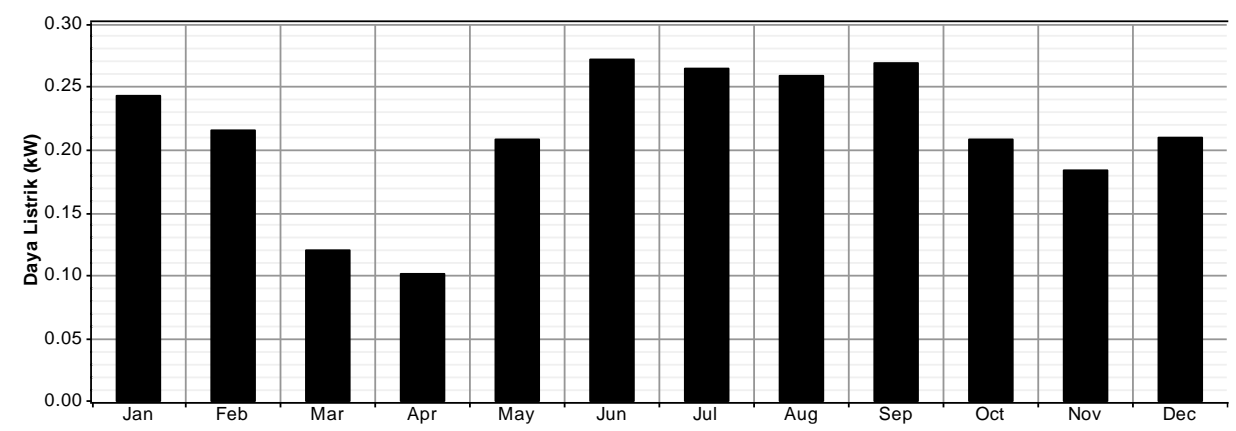

Gambar 7. Produksi listrik rata-rata per bulan

Setelah diterapkan kepada masyarakat Desa Temajuk, kemampuan PLTA dengan 1 unit AWI-E1000T mampu melayani beban 3 rumah dengan batasan pemakaian energi listrik ratarata setiap rumah sebesar $50 \mathrm{kWh}$ per bulan. Sedangkan jumlah rumah di Desa Temajuk ada sebanyak 612 rumah. Sehingga untuk melayani kebutuhan energi listrik seluruh masyarakat Desa Temajuk memerlukan PLTA dengan AWI-E1000T sebanyak 204 turbin angin.

Selanjutnya hasil analisis biaya untuk pembangkit listrik tenaga angin dengan menggunakan satu turbin angin AWI-E1000T ditunjukkan pada tabel 1. Dengan tingkat IRR= $5 \%$ biaya total yang diperlukan adalah sebesar \$16154 atau sekitar IDR 242 juta (asumsi \$1 = 
IDR 15.000) untuk menghasilkan energi listrik sebesar $1861 \mathrm{kWh} / \mathrm{tahun}$ dengan usia operasional selama 25 tahun.

Tabel 1. Analisis Biaya Pembangkit Listrik Tenaga Angin

\begin{tabular}{cccccc}
\hline Komponen & $\begin{array}{c}\text { Modal } \\
\mathbf{( \$ )}\end{array}$ & $\begin{array}{c}\text { Replacement } \\
\mathbf{( \$ )}\end{array}$ & $\begin{array}{c}\text { O\&M } \\
\mathbf{( \$ )}\end{array}$ & $\begin{array}{c}\text { Salvage } \\
\mathbf{( \$ )}\end{array}$ & $\begin{array}{c}\text { Total } \\
\mathbf{( \$ )}\end{array}$ \\
\hline Turbin Angin & 4000 & 1924 & 2819 & -394 & 8349 \\
Baterai & 2400 & 2081 & 3383 & -650 & 7213 \\
Inverter & 250 & 235 & 141 & -35 & 591 \\
Total & 6650 & 4240 & 6342 & -1078 & 16154 \\
\hline
\end{tabular}

Berdasarkan analisis biaya, komponen biaya terbesar dari PLTA adalah perangkat turbin angin dan baterai. Analisis ini belaku untuk satu unit turbin angin dengan spesifikasi output maksimum $1 \mathrm{~kW}$. Untuk memperbesar energi listrik yang dihasilkan oleh PLTA dapat dilakukan dengan instalasi beberapa unit turbin angin dengan spesifikasi yang sama. Dengan demikian kendala kegiatan pengabdian kepada masyarakat untuk elektrifikasi Desa Temajuk dengan menggunakan PLTA $1 \mathrm{~kW}$ adalah kemampuan PLTA yang hanya mampu melayani kebutuhan listrik untuk 3 rumah karena keterbatasan biaya investasi. Untuk elektrifikasi keseluruhan Desa Temajuk memerlukan biaya investasi yang sangat besar, yaitu sebesar $204 \mathrm{x}$ (IDR 242 juta).

\section{Simpulan}

Hasil kegiatan pengabdian kepada masyarakat dengan pemasangan satu unit turbin angin di Desa Temajuk memberikan kontribusi terhadap program kelistrikan nasional. Dengan menggunakan satu turbin angin AWI-E1000T maka mampu mencukupi kebutuhan listrik 3 rumah tangga apabila pemakaian energi listrik rata-rata setiap rumah sebesar $50 \mathrm{kWh}$ per bulan. Akan tetapi untuk memberikan jumlah energi listrik yang lebih besar, dapat dilakukan dengan pemasangan turbin angin lebih banyak lagi dengan memperhitungkan bahwa untuk PLTA dengan satu unit turbin angin AWI-E1000T memerlukan biaya sebesar IDR 242 juta dengan masa pemakaian selama 25 tahun. Dengan demikian kendala elektrifikasi Desa Temajuk dengan PLTA AWI-E1000T adalah karena membutuhkan biaya investasi yang sangat besar. Untuk memperkecil biaya investasi maka penerapan PLTA harus dihibrida dengan potensi energi lokal lainnya seperti: energi surya dan energi ombak/gelombang laut.

\section{Daftar Pustaka}

Adam, L. (2016). Dinamika sektor kelistrikan di Indonesia: Kebutuhan dan performa penyediaan. Jurnal Ekonomi Dan Pembangunan, 24(1), 29-41.

Aminudin, C. (2020). Keadilan ekologis dan kebijakan elektrifikasi perdesaan berbasis energi terbarukan lepas jaringan di Jawa Barat. Jurnal Ekologi, Masyarakat \& Sains, 1(1), 17-22.

Bahrami, A., Teimourian, A., Okoye, C.O., \& Khosravi, N. (2019). Assessing the feasibility of wind energy as a power source in Turkmenistan; a major opportunity for Central Asia's energy market. Energy, 183, 415-427.

Bupati Sambas (2019). Peraturan Bupati Sambas tentang: Rencana kerja pemerintah daerah Kabupaten Sambas tahun 2020. Sambas: Pemerintah Kabupaten Sambas. 
Hiendro, A., Kurnianto, R., Rajagukgul, M., Simanjuntak, Y.M., \& Junaidi (2013). Technoeconomic analysis of photovoltaic/wind hybrid system for onshore/remote area in Indonesia. Energy, 59, 652-657.

Menteri Desa, Pembangunan Daerah Tertinggal dan Transmigrasi (2019). Rencana strategis kementerian desa, pembangunan daerah tertinggal dan transmigrasi 2020-2024. Jakarta: Kementerian Desa, Pembangunan Daerah Tertinggal dan Transmigrasi.

Menteri Energi dan Sumber Daya Mineral RI (2018). Keputusan Menteri Energi dan Sumber Daya Mineral tentang: Pengesahan rencana usaha penyediaan tenaga listrik PT Perusahaan Listrik Negara (Persero) tahun 2018-2027. Jakarta: Kementerian Energi dan Sumber Daya Mineral.

Presiden Republik Indonesia (2018). Peraturan Presiden Republik Indonesia tentang: Strategi nasional percepatan pembangunan daerah tertinggal tahun 2015-2019. Jakarta: Pemerintah Republik Indonesia.

Rehman, S., Mohandes, M.A., \& Alhems, L.M. (2018). Wind speed and power characteristics using LiDAR anemometer based measurements. Sustainable Energy Technologies and Assessments, 27, 46-62.

Wind Turbine 1KW Catalogue. http://www.awing-i.com/english/1kW_wind_turbine.html

Yunita, A., Susanty, M., Pamungkas, G.A.D., \& Nugroho, H. (2019). Analisis kebutuhan untuk membangun media pembelajaran maya yang mendukung proyek energi baru dan terbarukan: Analisis kebutuhan pengguna. Jurnal Teknologia, 2(1), 120-131. 